doi: $10.3935 /$ rsp.v25i3.1583

\section{IZAZOVI PROVEDBE EUROPSKIH POLITIKA U HRVATSKOJ}

\section{Višnja Samardžija (ur.)}

Zagreb: Institut za razvoj i međunarodne odnose, 2018., 290 str.

Iako je Hrvatska proslavila svoje petogodišnje punopravno članstvo u EU, to uglavnom nije bilo popraćeno sustavnim analizama uspjeha i poteškoća u provedbama europskih politika kod nas. Ipak, ovo stanje se donekle popravilo nedavnim objavljivanjem publikacije o ovoj temi. U okviru aktivnosti Europske komisije u sklopu Erasmus+ Jean Monnet potpore institucijama »POLO-Cro28 - Opservatorij politika u Hrvatskoj«, Institut za razvoj i međunarodne odnose iz Zagreba tiskao je knjigu Izazovi provedbe europskih politika u Hrvatskoj ${ }^{1}$, koju je uredila Višnja Samardžija. U šest cjelina, veća skupina autora vrlo argumentirano i znalački izlaže sve složene probleme koji se očituju u Hrvatskoj u provedbi europskih politika te na temelju analize iskustava i primjera dobre prakse daju jasne preporuke za poboljšanje njihove provedbe. Multidisciplinarna analiza politika obuhvaća provedbu Europskog semestra te mjere u području unaprjeđenja konkurentnosti, kohezijske politike, zapošljavanja mladih, zaštite okoliša i energetske politike. Posebno je korisno što je publikacija dvojezična, najvažnije poruke iz svakog priloga pripremljene su i na engleskom.

U kraćem Predgovoru urednica pojašnjava sam projekt POLO-Cro28 čiji je cilj bio praćenje razvoja politika i inicijativa Europske unije na šest navedenih područja te kritički razmotriti značaj, napredak i izazove pri njihovoj provedbi u Hrvatskoj i odabranim novim državama članicama EU-a. Riječ je o Bugarskoj, Češkoj, Mađarskoj, Poljskoj, Rumunjskoj, Slovačkoj i Sloveniji, s kojima Hrvatska dijeli slične izazove $\mathrm{u}$ provedbi reformi na gospodarskom i socijalnom planu. U analizi su korišteni mnogobrojni izvori, ponajviše izvješća Europske komisije, nacionalni strateški dokumenti, akademski izvori te potrebni statistički pokazatelji. Osim spomenutih izvora, istraživanje se nadovezuju i na spoznaje proizašle iz rasprava na okruglim stolovima organiziranim u okviru projekta za svaku tematsku cjelinu koji su organizirani u Zagrebu, Osijeku i Opatiji.

U prvom prilogu Višnja Samardžija, Krešimir Jurlin i Ivana Skazlić pojašnjavaju značenje Europskog semestra, što je važan proces kojim Europska komisija nastoji dati prijedloge za poboljšanje stanja u zemljama članicama ne samo u upravljanju javnih financija, nego i na tržištu rada, mirovinskom i zdravstvenom osiguranju, javnoj upravi, poslovnoj klimi i konkurentnosti, sve u cilju postizanja održivog i snažnog gospodarskog razvoja. Europski semestar ima ključnu ulogu u provedbi i nadgledanju provedbe ciljeva desetogodišnje strategije EU-a za rast i zapošljavanje Europa 2020. U okviru Europskog semestra zemlje članice EU-a usklađuju svoje proračunske i ekonomske politike s ciljevima i pravilima dogovorenim na razini Unije te određuju i provode reforme sa svrhom poticanja gospodarskog rasta. Kako je riječ o razmjerno novom i složenom instrumentu koordinacije i nadzora, provedbeni mehanizmi Europ-

1 Publikacija je dostupna na mrežnoj stranici: http://www.irmo.hr/hr/publikacije/objavljena-knjigaizazovi-provedbe-europskih-politika-u-hrvatskoj-the-challenges-of-european-policies-implementation-incroatia/. 
skog semestra još se razvijaju i poboljšavaju. Tako je Komisija napravila nekoliko važnih promjena u procesu Europskog semestra, ponajviše u većoj usmjerenosti preporuka na prioritetna područja djelovanja i skraćivanju teksta samih preporuka kao i po pitanju ranijeg objavljivanja preporuka za gospodarsko stanje europodručja kao cjeline. Ujedno je u cilju poboljšanja upravljanjem reformama poticanja kohezije, konkurentnosti, produktivnosti i održivog rasta, Komisija 2015. godine osnovala Službu potpore strukturnim reformama. Taj mehanizam mogao bi značajno pomoći Hrvatskoj kod izrade strateških dokumenata iz područja konkurentnosti, pametne specijalizacije $\mathrm{i}$ investicija.

Hrvatska je 2013. godine prije ulaska u punopravno članstvo EU-a, bila dobrovoljno i neformalno uključena u Europski semestar te pripremila i podnijela Nacionalni program reformi, ali na temelju toga nije dobila preporuke. Članstvom u Uniji, preuzela je obvezu redovnog sudjelovanja u Europskom semestru, pripreme strateških dokumenata na godišnjoj razini i provedbe dobivenih preporuka koje su nužne kako bi se ostvarilo suvremeno i otvoreno tržišno gospodarstvo. Osim zavidnih poboljšanja u konsolidaciji javnih financija, posebice značajnog smanjivanja proračunskog deficita i boljeg upravljanja javnim dugom, što je omogućilo izlaz iz procedure u slučaju prekomjernog deficita, Hrvatska je u drugim reformskim područjima ostvarila slab napredak. Zato ne čudi kako se preporuke Europske komisije uglavnom ponavljaju iz godine u godinu. U prilogu se zaključuje da bi daljnja odgoda reformi mogla ozbiljno usporiti stope gospodarskog rasta, a time bi Hrvatska potvrdila svoj nepovoljan položaj jedne od najsiromašnijih članice EU-a.

Možda i najveći problem hrvatskog gospodarstva je niska razina konkurentnosti, o čemu pišu Krešimir Jurlin, Višnja Sa- mardžija i Martina Basarac Sertić. Autori u svom prilogu polaze od analize strateškog pristupa, politika, mehanizama i instrumenata EU-a kojima se nastoji potaknuti konkurentnost država članica i Unije u cjelini. Poticanje rasta i konkurentnosti u svrhu gospodarskog razvoja i ostvarivanja ciljeva Strategije Europa 2020. svrstava se među najvažnije zadatke prioritete Komisije i država članica EU-a u razdoblju nakon gospodarske krize. Strategijom Europa 2020. nastoje se riješiti strukturne slabosti dosadašnjeg modela rasta stvaranjem uvjeta za pametan, održiv i uključiv rast. EU nastoji integriranim politikama, mehanizmima i instrumentima doprinijeti poboljšanju konkurentnosti zemalja članica, prije svega bržom provedbom strukturnih promjena, poticanjem okruženja pogodnog za razvoj i međusobnom suradnjom poduzetnika. U predlaganju i provedbi mjera industrijske politike posebna pozornost posvećuje se razvoju »pametnog « zakonodavstva i analizi učinaka zakonodavstva na konkurentnost, osiguravanju boljeg pristupa mogućnostima financiranja, jačanju unutarnjeg tržišta uklanjanjem postojećih zapreka, unaprjeđenju sustava prava intelektualnog vlasništva, poboljšanju pravila o tržišnom natjecanju, jačanju energetske, transportne i komunikacijske infrastrukture te unaprjeđenju europske standardizacije. Vijeće EU-a donijelo je 2016. godine Preporuku o osnivanju nacionalnih odbora za produktivnost u europodručju što bi trebalo omogućiti praćenje učinaka i politika u području konkurentnosti, dugoročnih odrednica poboljšanja produktivnosti i konkurentnosti, uključujući inovativnost i privlačenje investicija, poslovnog i ljudskog kapitala, kao i drugih čimbenika koji utječu na cijene i kvalitetu proizvoda i usluga.

Jurlin i suradnice uspoređuju najvažnije odrednice nacionalnih strategija pametne specijalizacije te investicijske poticaje $\mathrm{i}$ 
prepreke ulaganju. U razmatranju najvažnijih faktora konkurentnosti u Hrvatskoj i usporednim državama članicama (s naglaskom na visoko obrazovanje, poslovnu sofisticiranost i inovativnost) te strukturne promjene gospodarstava, ističu uglavnom loš položaj Hrvatske, posebno u području inovativnosti. Hrvatska je prema posljednjim raspoloživim podacima vrlo nisko pozicionirana na 106. mjestu, a ujedno se očituje i stalno pogoršanje pozicije $u$ odnosu na početnu 2007. godinu kada je bila na 51 . mjestu ljestvice. U zaključcima, podsjeća se kako je EU opterećena nedovoljnim rastom produktivnosti što je prepreka jačem ukupnom rastu. Unutar Unije i nadalje su prisutne značajne gospodarske i socijalne nejednakosti, a jedinstveno tržište još uvijek ne ostvaruje sve svoje mogućnosti. Imajući u vidu stagnaciju ukupne nacionalne konkurentnosti, Hrvatska treba mnogo odlučnije i brže pristupiti rješavanju problema u područjima inovativnosti, obrazovanja i poslovne sofisticiranosti. Mogući pozitivni pomaci na ljestvicama konkurentnosti privukli bi ulaganja, potaknuli izvoz i tako utjecali i na jačanje gospodarskog rasta temeljem porasta produktivnosti. U ublažavanju nepovoljnog trenda smanjivanja inovativnosti, posebnu pozornost potrebno je usmjeriti na unaprjeđenje suradnje poslovnog sektora i znanstvene zajednice.

Kohezijska politika predmet je istraživanja Sanje Maleković, Jakše Puljiza i Ivane Keser. U radu se uspoređuju učinci kohezijske politike za Hrvatsku, Sloveniju i Slovačku. Posebno se istražuju poteškoće apsorpcijskog kapaciteta kao i čimbenici koji sprječavaju učinkovitije korištenje fondova EU-a. Na razini EU-a, važna novina bilo je uvođenje »tematske koncentracije« koja države obvezuje da svoje investicije sufinancirane sredstvima iz europskih strukturnih i investicijskih fondova (ESI) bolje usklade s ciljevima Europe 2020. i osobito s područjima koja obuhvaćaju četiri tematska cilja. To su istraživanje i razvoj, informacijske i komunikacijske tehnologije, mala i srednja poduzeća te niskougljično gospodarstvo. Nadalje, pravila vezana za ESI fondove dovela su do veće koncentracije fondova u manjem broju najvažnijih područja jasno povezanih s prioritetima na razini EU-a što bi trebalo poboljšati učinkovitost ulaganja i smanjiti probleme rasipanja investicija na previše sektorskih politika. EU u politici ulaganja sada mnogo veće težište stavlja na rezultate, s postavljanjem jasnih i mjerljivih ciljeva za ocjenjivanje uspješnosti programa sufinanciranih iz ESI fondova. To podrazumijeva pozornije praćenje i evaluaciju financiranih programa, pri čemu se ističu višegodišnje strateško planiranje, primjena načela partnerstva kao i mogućnosti za učenje o sektorskim politikama. Provedene evaluacije, na primjeru Slovenije, pokazale su kako postoji još mnogo prostora za poboljšanja $\mathrm{u}$ provedbi kohezijske politike. Iako su u Hrvatskoj značajna sredstva bila uložena u jačanje administrativnog kapaciteta, rezultati su bili prilično loši i nisu se značajnije poboljšali iako se broj osoblja znatno povećao. To je na nacionalnoj razini djelomično posljedica razmjerno čestih promjena državnog vodstva i nedovoljne usmjerenosti nositelja vlasti na ostvarivanje dugoročnih i održivih rezultata važnih za promicanje razvojnih promjena.

Spomenuta ograničenja jasno se uočavaju na lokalnoj i regionalnoj razini, pri čemu su ipak pojedine lokalne jedinice, a pogotovo županije ostvarile zavidne rezultate u privlačenju europskih sredstava. Većina općina dosad uopće nije dobila sredstva iz ESI fondova. To su jedinice koje ne ulažu u razvijanje kapaciteta i vještina za pripremu i provedbu projekata te gotovo i ne koriste tuđa iskustava i pozitivne primjere povlačenja sredstava iz EU fondova. 
Istina, često su razlozi za nekorištenje ili za nedovoljno korištenje ESI fondova također uzrokovani dugim administrativnim postupcima, prijedlozima i kašnjenjima na nacionalnoj razini, kašnjenjem s alokacijama i ugovornim procedurama, čestim promjenama u uvjetima i/ili potrebnoj dokumentaciji i slično. Usprkos svemu, očituju se poboljšanja te su pripreme za kohezijsku politiku kao i za privlačenje i iskorištavanje EU sredstava dale važan poticaj boljem oblikovanju regionalne politike Hrvatske. Tako je kohezijska politika omogućila značajne pozitivne promjene i pomake $\mathrm{u}$ regionalnoj politici Hrvatske i u ukupnom vođenju javnih politika.

Hrvoje Butković svoj je prilog posvetio nezaposlenosti mladih. Nezaposlenost je bez sumnje velik društveni i osobni problem, pogotovo ako pogađa mlade osobe i ako postaje dugotrajna, tako da se na posao čeka više od godine dana. U razdoblju 1998.-2008. nezaposlenosti mladih u Hrvatskoj bila je u apsolutnom i relativnom smanjivanju, ali se stanje pogoršalo nakon izbijanja gospodarske krize 2008. godine. U tekstu se pojašnjava značenje programa Garancija za mlade u kontekstu Europske unije, s posebnim naglaskom na iskustva Slovenije i Poljske te se daje osvrt na značenje tog sustava i njegovu budućnost $u$ Hrvatskoj. Programi Garancije za mlade provode se u gotovo svim članicama EU-a i obuhvaćaju više aktivnosti zapošljavanja, obrazovanja i usavršavanja. Njima se nastoji osigurati da države članice ponude svim mladim ljudima kvalitetan posao, nastavak školovanja, naukovanje ili stažiranje u roku od četiri mjeseca od izlaska iz formalnog obrazovanja ili gubitka zaposlenja. Ako se Garancijom za mlade kao dijelom aktivnih politika tržišta rada ne uspije sniziti agregatna razina nezaposlenost, može se smatrati da se time ipak doprinosi lakšem izlaska mladih iz nezaposlenosti i nji- hovom boljom pripremom za tržište rada.

Nezaposlenost i niske stope aktivnosti uglavnom su posljedica nedovoljne potražnje za radnom snagom i neusklađenosti ponude i potražnje na tržištu rada. Razmjerno visoke realne plaće u odnosu na produktivnost, institucionalna strogost i značajna neusklađenost ponude i potražnje u pogledu obrazovanja i stručnosti čine se najvećim zaprekama za dinamičnije djelovanje tržišta rada. Sve navedeno neposredno i pojačano utječe na sužene mogućnosti zapošljavanja mladih i slijedom toga njihovu visoku nezaposlenost. Butković vrlo argumentirano i jasno iznosi svoje stavove te naglašava potrebu sveobuhvatne smislene politike usmjerene na ublažavanje nezaposlenosti mladih. Pristupanjem EU, Hrvatska je prihvatila Garanciju za mlade kao ključni element poboljšanja položaja mladih na tržištu rada i osiguranja njihove budućnosti, kao i smanjenja rastućeg broja mladih nezaposlenih osoba. Autor vjeruje kako bi u poboljšanju položaja mladih na tržištu rada, Hrvatska među ostalim morala pojačati napore u borbi protiv segmentiranja tržišta rada koje naročito pogađa mlade, dodatno razvijati model dualnog strukovnog obrazovanja i osposobljavanja, unaprijediti cjeloživotno obrazovanje te povećati sadašnju nisku stopu završavanja fakulteta.

Sanja Tišma i Marina Funduk pišu o mjerama za zaštitu okoliša u EU i četiri nove članice: Bugarskoj, Hrvatskoj, Rumunjskoj i Sloveniji. Hrvatska je tijekom pristupnog razdoblja preuzela i uskladila opsežno zakonodavstvo vezano uz očuvanje okoliša, a njegova je provedba danas jedan od najvećih izazova, ponajviše zbog velikih ulaganja u potrebnu infrastrukturu. U dionici o razvoju politika zaštite okoliša u EU, autorice pojašnjavaju kako je ona imala tri ključne faze. Prva faza počinje 1972. godine, kada je EU pripremila institucionalnu osnovu za razvoj politika zašti- 
te okoliša te odredila najvažnija strateška načela. Druga faza vezana je uz usvajanje Jedinstvenog europskog akta 1987. godine, kojim su ojačani pravni temelji politike zaštite okoliša, utvrđeni ciljevi i dopunjene procedure. Treća faza započela je donošenjem Ugovora iz Maastrichta 1992. godine, kada zaštita okoliša postaje jedna od najvažnijih politika EU-a i traje do danas. Politika zaštite okoliša EU-a danas obuhvaća više od 300 različitih pravnih dokumenata (direktive, propisi, odluke) koje sve države članice moraju prenijeti u nacionalna zakonodavstva. U europskom okviru politike zaštite okoliša do 2020. godine, utvrđeno je devet prioriteta, od koji su tri ključna: (1) zaštititi, očuvati i povećati prirodni kapital Unije, (2) pretvoriti Uniju u resursno učinkovito, zeleno i konkurentno gospodarstvo s niskom razinom emisija ugljičnog dioksida te (3) zaštititi građane Unije od pritisaka i opasnosti za njihovo zdravlje i blagostanje povezano s okolišem.

Sve promatrane države članice suočavaju se s gubitkom bioraznolikosti zbog gubitka staništa. U politici zaštite prirode EU-a, postignuti su pozitivni rezultati pa je u ekološku mrežu za zaštitu ptica, biljaka, sisavaca, gmazova i riba, uključeno oko 30000 područja na gotovo $20 \%$ teritorija EU-a što je čini najvećim sustavom očuvanih područja na svijetu. U Hrvatskoj je poseban problem prisutnost preostalih minskih polja i neeksplodiranih eksplozivnih sredstava u nacionalno zaštićenim ekološkim područjima. Politika zaštite i upravljanja vodama EU-a obuhvaća vrlo opsežno zakonodavstvo, s nizom usvojenih direktiva, pri čemu se sve više naglašava holistički pristup. Iako je ponekad vodoopskrbna infrastruktura zastarjela (posebice u Bugarskoj), duljina vodovodne mreže postupno se povećava i porastao je broj potrošača priključenih na sustav javne vodoopskrbe. Ipak, sve promatrane ze- mlje imaju velike potrebe za ulaganjima $u$ izgradnju odgovarajuće infrastrukture i za sustav javne vodoopskrbe, pa će tu trebati značajna financijska izdvajanja. Stoga su sve promatrane države članice za razdoblje 2014.-2020. alocirale sredstva iz Kohezijskog fonda za prioritete vezane za vodnu infrastrukturu. U politici gospodarenja otpadom EU-a, javlja se snažna inicijativa prelaska s dosadašnjeg linearnog na kružno gospodarstvo, čime bi se produljio životni vijek materijala i proizvoda te otpad sveo na najmanju moguću mjeru. Stoga u prijedlozima za poboljšanje autorice ističu kako je u Hrvatskoj u području gospodarenja otpadom potrebno u skoroj budućnosti ostvariti ključne iskorake i unaprijediti sustav gospodarenja otpadom prema kružnom gospodarstvu. Očekuje se provedba mjera za postizanje smanjenja, ponovne uporabe, odvajanja i recikliranja otpada u skladu s hijerarhijom gospodarenja otpadom te poticanje ulaganja u sortirnice i centre za ponovnu uporabu.

Ana-Maria Boromisa proučava u kojoj je mjeri EU stvarno energetska unija i kakvo je stanje u pogledu energetske učinkovitosti u Hrvatskoj i odabranim novim članicama. EU želi imati vodeću ulogu u proizvodnji obnovljive energije i borbi protiv klimatskih promjena. Cilj razvoja Energetske unije je sigurna, pristupačna i klimatski prihvatljiva energija u Europi. Energetska unija sadrži pet dimenzija: (i) sigurnost, solidarnost i povjerenje, (ii) integracija unutarnjeg energetskog tržišta, (iii) energetska učinkovitost, (iv) klimatske aktivnosti - dekarbonizacija gospodarstva i (v) istraživanje, razvoj i konkurentnost. Energetska unija trebala bi omogućiti postizanje uobičajenih ciljeva energetske politike (sigurnost opskrbe, financijsku dostupnost za korisnike, prihvatljivost za okoliš) uz poticanje energetske tranzicije, odnosno veće konkurencije na tržištu i usklađivanje 
s klimatskom politikom. Boromisa daje vrlo koristan pregled projekata od zajedničkog interesa kao i pregled značajnijih projekata, među koje se ubraja i terminal za ukapljeni prirodni plin na Krku. Taj se projektuuu čini važnim čimbenikom diversifikacije opskrbe prirodnim plinom i povećanja sigurnosti opskrbe prirodnim plinom srednje i jugoistočne Europe, ali nailazi i na snažno protivljenje lokalne zajednice. Od investicija na nacionalnoj razini u $\mathrm{Hr}-$ vatskoj podrobno se pojašnjava Projekt Plomin C, odnosno rekonstrukcija termoelektrane Plomin. Tako bi se trebalo omogućiti zadržavanje prve kategorije kakvoće zraka, uz smanjenje emisija štetnih plinova i povećanje sigurnosti opskrbe. Nažalost, nema javno dostupnih informacija o statusu projekta i napretku u pripremi.

U skladu s Nacionalnim programom reformi za 2016., u Hrvatskoj je Strategija niskougljičnog razvoja trebala biti prihvaćena do kraja 2016. Taj je rok pomaknut na lipanj 2017., ali spomenuta Strategija još nije usvojena. Postojeći energetski strateški dokumenti RH - Strategija energetskog razvoja i Nacionalni akcijski plan za obnovljive energije - ne daju nikakve smjernice za prilagodbe klimatskim promjenama energetskog sektora. Ipak, programi Vlade i drugi strateški dokumenti ističu važnost investicija za postizanje ciljeva energetske politike. Na primjer, Strategija energetskog razvitka procjenjuje da je za ostvarivanje njezinih ciljeva u razdoblju do 2020. potrebno oko 15 milijardi eura, od toga oko $60 \%$ za ulaganja u elektroenergetski sustav, 30\% u sustav proizvodnje, prerade, transporta i skladištenja nafte i plina te oko $10 \%$ u toplinski sustav. Iako je svaka hrvatska Vlada predviđala ulaganja u energeti$\mathrm{ku}$, veća ulaganja nisu ostvarena. Stoga autorica u prijedlozima za poboljšanje među ostalim navodi kako je potrebno jasno definirati ciljeve javnih investicijskih projeka- ta, dinamiku provedbe, praćenja i revizije. Investicijske odluke trebalo bi donositi na temelju procjene održivosti i doprinosa ciljevima svakog pojedinačnog projekta. Pritom je nužno definirati prioritete te $u$ skladu s prioritetima alocirati financijske $i$ ljudske resurse za pripremu i provedbu.

U dodatku publikaciji, Hrvoje Butković iznosi pojedinosti o samom projektu. Istaknuto je da se tijekom provedbe projekta vodilo računa i o umrežavanju sa sličnim projektima, a putem posebne mrežne stranice postignuta je visoka razina vidljivosti projekta.

Knjiga Izazovi provedbe europskih politika u Hrvatskoj vrlo je zanimljiv i koristan skup tekstova koji s različitih motrišta proučavaju provedbu europskih politika $\mathrm{u}$ Hrvatskoj. Najkraća je poruka kako ta provedba nije posve zadovoljavajuća te da su potrebni ozbiljni pomaci kako bi se unaprijedilo trenutačno stanje. Provedba reformi predstavlja nužnost u svim analiziranim politikama, a u tome EU može pomoći državama članicama svojim instrumentima i mehanizmima. Možemo se nadati da će ova publikacija biti poticaj za promjene, pa će u doglednoj budućnosti neka slična analiza navoditi Hrvatsku kao primjer uspješne provedbe europskih politika.

Predrag Bejaković

Institut za javne financije, Zagreb 